Volume 6, Issue 2, Year 2020, Pages 57-65

URL http://jurnal.unissula.ac.id/index.php/jnm

DOI http://dx.doi.org/10.30659/nurscope.6.2.57-65

\title{
Dukungan sosial dan kecerdasan spiritual sebagai faktor yang memengaruhi stres Perawat di masa pandemi Covid-19
}

\author{
Nurmukaromatis Saleha ${ }^{1 *}$, Rina Delfina ${ }^{2}$, Nurlaili Nurlaili ${ }^{3}$, Fourni Ardiansyah ${ }^{4}$, Mercy Nafratilova $^{5}$ \\ ${ }^{1,2,3}$ Program Studi D3 Keperawatan, Universitas Bengkulu, Indonesia \\ ${ }^{4}$ Departemen Keperawatan Manajemen, RSUD dr. M. Yunus, Indonesia \\ ${ }^{5}$ Departemen Keperawatan Anak, RSUD dr. M. Yunus, Indonesia \\ *Corresponding author: nsaleha@unib.ac.id
}

\begin{abstract}
ABSTRAK
Pendahuluan: Perawat sebagai pemberi pelayanan kesehatan dengan sifat profesinya sangat sulit untuk menghindari kontak yang erat terhadap pasiennya. Tingginya risiko keterpaparan infeksi Covid-19 serta faktor-faktor lain memengaruhi psycological well being perawat yang berdampak pada resistensi mereka terhadap profesi. Tujuan penelitian ini untuk melihat pengaruh faktor dukungan social dan kecerdasan spiritual perawat terhadap stress. Metode: Studi ini merupakan cross sectional dengan alat pengumpulan data menggunakan kuisioner modifikasi dari ISEL untuk dukungan sosial, SISRI untuk kecerdasan spiritual dan PSS untuk menilai stress. Hasil: Data dianalisa dengan regresi linier berganda, didapatkan hasil nilai $R=0,726 ; R^{2}=0,527 ; F=59,105 ; p=0,000(p<0,000)$. Simpulan: bahwa dukungan sosial dan kecerdasan spiritual perawat secara simultan memiliki pengaruh terhadap stres sebesar $52,7 \%$ sisanya $47,3 \%$ dipengaruhi oleh faktor lain yang tidak menjadi fokus penelitian ini.
\end{abstract}

Kata Kunci: Covid-19; stress perawat; dukungan sosial; kecerdasan spiritual

Social support and spiritual intelligence as factors affecting Nurse stress in the Covid-19 pandemic era

\begin{abstract}
Introduction: It is very difficult for the nurse as a health care provider to avoid close contact with the patient. The high risk of exposure to Covid-19 infection and other factors affect the psychological well being of nurses which has an impact on their resistance to the profession. The aim of this study was to investigated the influence of social support factors and nurses' spiritual intelligence on stress. Methods: This study was a cross sectional study with data collection tools using a modified questionnaire from ISEL for social support, SISRI for spiritual intelligence and PSS for assessing stress. Results: The data were analyzed using multiple linear regression, the results obtained were the value of $R=0.726 ; R^{2}=0.527 ; F=59.105 ; p=0.000(p<0.000)$. Conclusions: Social support and spiritual intelligence of nurses simultaneously have an effect on stress by $52.7 \%$, the remaining $47.3 \%$ is influenced by other factors which are not the focus of this study.
\end{abstract}

Keywords: Covid-19; stress nurse; social support; spiritual intelligence

How to Cite: Saleha, N., Delfina, R., Nurlaili, N., Ardiansyah, F., \& Nafratilova, M. (2020). Dukungan sosial dan kecerdasan spritual sebagai faktor yang memengaruhi stres Perawat di masa pandemi Covid-19. NURSCOPE: Jurnal Penelitian dan Pemikiran Ilmiah Keperawatan, 6 (2), 57-65

\section{PENDAHULUAN}

Wabah Covid-19 berkembang dengan cepat menjadi masalah Kesehatan utama di berbagai belahan dunia. Tanggal 11 Maret 2020 World Health Organisation (WHO) menetapkan wabah ini sebagai Pandemi. Tingginya angka morbiditas dan mortalitas yang disebabkan Covid-19 menimbulkan kecemasan dan stres 
Volume 6, Issue 2, Year 2020, Pages 57-65

secara umum. Sementara itu angka kematian tenaga Kesehatan di Indonesia lebih tinggi dibanding negara lain, yaitu sebesar 1,2\% (IDI, 2020). International Council Nursing menyebutkan sebanyak 1500 orang perawat telah meninggal dunia dalam penanganan wabah ini (Kompas, 2020). Berdasarkan situs CNN online tanggal 5 Agustus 2020, Indonesia dinyatakan menempati urutan ke 3 angka kematian tenaga Kesehatan akibat Covid-19 didunia. Konsekuensi yang harus dihadapi oleh tenaga Kesehatan adalah menjadi cluster untuk kejadian kasus konfirmasi. Perawat merupakan tenaga Kesehatan paling banyak di pusat-pusat pelayanan kesehatan serta memiliki kontak yang lebih lama dengan pasien dibanding tenaga Kesehatan lainnya. Perawat menjadi garda terdepan dalam penanganan pasien Covid-19. Dengan sifat profesinya tersebut menempatkan tenaga medis berada dalam risiko tinggi tertular Covid-19. Mengingat hal tersebut maka tindakan untuk mengawasi dan mengendalikan infeksi merupakan hal yang penting guna memproteksi tenaga kesehatan (Luo et al., 2020; Wei, Wang, \& Zhang, 2020).

Risiko terpapar didapat dari rekan kerja, dari pasien juga dari orang-orang yang tampak sehat namun ternyata membawa virus penyebab Covid-19. Kejadian ini menimbulkan kecemasan dan stress psikologis bagi perawat dalam menjalankan tugasnya. Kekhawatiran menularkan penyakit pada keluarga, perubahan pola kerja, penggunaan alat pelindung diri dalam jangka waktu yang lama, keterbatasan Alat Pelindung Diri (APD), kelelahan fisik dan stigma masyarakat merupakan faktor-faktor stress psikologis yang dihadapi perawat. Menyaksikan rekan kerja yang sakit bahkan meninggal, semua hal tersebut menguras energi fisik dan mental perawat. Kondisi tersebut menjadi stressor yang dapat berkembang menjadi gejala stres post trauma untuk 3 bulan kemudian. Pandemi ini merupakan bencana non alam dimana terjadi penderitaan fisik secara bersama dan angka kematian yang tinggi. Beberapa penelitian menunjukkan bahwa petugas kesehatan yang menangani wabah SARS 2003 dan MERS 2015 sangat rentan mengalami tekanan psikologis (Albott et al., 2020; Rejo et al., 2020).

Proses mempertahankan kesehatan mental perawat adalah penting guna meningkatkan retensi mereka terhadap profesi. Covid-19 menjadi tantangan bagi Rumah Sakit dan pusat-pusat pelayanan Kesehatan yang memperkerjakan perawat. Pada masa sebelum pandemi dengan situasi normalpun profesi ini telah merupakan profesi yang penuh dengan tekanan emosional. Sementara itu Covid-19 membawa perubahan yang belum pernah terjadi sebelumnya sehingga pola kerja berubah, terjadi kecemasan serta stresor yang berkaitan dengan morbiditas dan mortalitas. Pengelolaan stresor yang baik diawali dengan melihat faktor yang dapat memengaruhinya (Kim, Lee, \& Cho, 2020). Penelitian ini bertujuan untuk melihat bagaimana pengaruh dukungan sosial dan kecerdasan spiritual perawat terhadap stres yang dialami perawat. Sebagai pemberi layanan kesehatan kepada masyarakat tentunya dukungan moril dari masyarakat dapat dijadikan amunisi tersendiri yang dapat menguatkan mental perawat guna meningkatkan performa kinerjanya. Sementara itu kecerdasan spiritual merupakan salah satu unsur penting yang dapat meningkatkan psycological well being yang menjadi kebutuhan bagi setiap individu. Kondisi psycological well being yang baik akan memengaruhi performa kinerja perawat.

\section{METODE}

Penelitian ini merupakan studi Cross Sectional yang dilakukan pada 109 orang perawat di Kota Bengkulu. Responden merupakan seluruh perawat baik di lini depan maupun non lini depan yang menjalankan tugas di era pandemic Covid-19. Pengumpulan data dilakukan pada bulan September sampai dengan Oktober 2020 melalui survei online dengan tekhnik pengambilan sampel simple random sampling. Kuesioner yang digunakan diadaptasi dari Interpersonal Support Evaluation List (ISEL) untuk dukungan sosial dan Spiritual Intelligence Self-Report Inventory (SISRI) untuk kecerdasan spiritual perawat. kedua kuesioner telah diuji 
validitas reabilitas untuk ISEL didapatkan nilai alpha croncbach's 0,840 dan 0,92 untuk SISRI. Data diolah dengan menggunakan uji statistik regresi linier ganda dengan metode Enter. Penelitian ini telah lulus uji etik dari Komite Etik Penelitian Kesehatan Fakultas Kedokteran dan Ilmu Kesehatan Universitas Bengkulu dengan no surat 226/UN30.14.9/LT/2020.

\section{HASIL DAN PEMBAHASAN}

Gambaran 109 perawat yang berpartisipasi dalam penelitian ini diuraikan pada tabel 1. Usia responden paling tua adalah 53 tahun dengan rerata usia 36,77. Responden memiliki rerata pengalaman lama kerja 11,75 tahun. Perawat perempuan sebanyak $72,5 \%$ atau 79 orang. Pendidikan terakhir responden paling banyak adalah S1 Keperawatan yaitu sebanyak 50 orang atau $45,9 \%$.

Tabel 1. Karakteristik perawat responden penelitian pengaruh dukungan sosial dan kecerdasan spiritual terhadap stres bekerja di Era Pandemi Covid-19 ( $n=109)$

\begin{tabular}{|c|c|c|c|c|}
\hline Karakteristik & Min & $\operatorname{Max}$ & Mean & $\begin{array}{l}\text { Standard } \\
\text { deviation }\end{array}$ \\
\hline Usia & 21 & 53 & 36,77 & 6,88 \\
\hline Lama bekerja & 1 & 32 & 11,75 & 7,26 \\
\hline Karakteristik & & $\mathbf{n}$ & & \\
\hline \multicolumn{5}{|l|}{ Jenis Kelamin } \\
\hline Laki-laki & & 30 & & \\
\hline Perempuan & & 79 & & \\
\hline Pendidikan terakhir & & 30 & & \\
\hline $\begin{array}{l}\text { D3 } \\
\text { S1 }\end{array}$ & & 50 & & \\
\hline Ners & & 27 & & \\
\hline S2 & & 2 & & \\
\hline \multicolumn{5}{|l|}{ Tempat Tugas } \\
\hline Lini depan & & 55 & & \\
\hline Non Lini depan & & 54 & & \\
\hline \multicolumn{5}{|l|}{ Status Nikah } \\
\hline Belum Nikah & & 14 & & \\
\hline Nikah & & 91 & & \\
\hline Singgle Parent & & 4 & & \\
\hline
\end{tabular}

Tabel 2 menggambarkan data berdistribusi normal dengan nilai signifikasi $p=0,139$. Didapatkan rerata dukungan sosial pada penelitian ini sebesar 42,23 lebih rendah dari nilai tengah dengan kategori rendah. Sementara itu untuk kecerdasan spiritual perawat didapatkan nilai rerata sebesar 36,61 dengan nilai tertinggi 61 mendekati nilai tertinggi pada possible range 68 dengan rerata stres perawat adalah 9,66 dengan kategori stres ringan.

Tabel 2. Gambaran dukungan sosial, kecerdasan spiritual dan kondisi stress yang dialami perawat yang bekerja di era pandemi Covid-19 ( $n=109)$

\begin{tabular}{lccccc}
\hline \multicolumn{1}{c}{ Variabel } & P value & Posible Range & Nilai Tengah & Actual Range & Mean \\
\hline Dukungan Sosial & & $22-88$ & 55 & $22-67$ & 42.23 \\
Kecerdasan Spritual & 0,139 & $17-68$ & 42,5 & $17-61$ & 36.61 \\
Kondisi Stres & & $0-40$ & 20 & $0-24$ & 9.66 \\
\hline
\end{tabular}


Volume 6, Issue 2, Year 2020, Pages 57-65

Pada tabel 3 didapatkan gambaran korelasi yang erat antara dukungan sosial dan kecerdasan spiritual perawat terhadap stress yang dialami perawat yang bertugas di era pandemi Covid-19 $(p=0,000)$ dengan sifat hubungan terbalik. Artinya semakin tinggi dukungan social dan kecerdasan spiritual maka stress menjadi rendah. Kedua faktor tersebut secara simultan memengaruhi stres perawat sebesar $51,8 \%$ sisanya $47,3 \%$ dipengaruhi faktor lain diluar fokus penelitian ini.

Tabel 3. Pengaruh dukungan sosial dan kecerdasan spiritual perawat terhadap stres bekerja diera pandemi Covid-19 ( $n=109)$

\begin{tabular}{|c|c|c|c|c|c|c|}
\hline \multicolumn{2}{|c|}{ Anova Test } & Variabel & \multicolumn{2}{|c|}{$\begin{array}{c}\text { Unstandardized } \\
\text { Coefficients }\end{array}$} & \multirow[t]{2}{*}{ Sig } & \multirow[t]{2}{*}{$\begin{array}{c}\text { Adjusted } R \\
\text { Square } \\
\end{array}$} \\
\hline $\mathrm{F}$ & Sig & & $B$ & $\begin{array}{l}\text { Std. } \\
\text { Error }\end{array}$ & & \\
\hline 59,105 & 0,000 & $\begin{array}{l}\text { Constant } \\
\text { Dukungan sosial } \\
\text { Kecerdasan spritual }\end{array}$ & $\begin{array}{l}23.536 \\
-0,205 \\
-0,143\end{array}$ & $\begin{array}{l}1,328 \\
0,031 \\
0,032\end{array}$ & $\begin{array}{l}0,000 \\
0,000 \\
0,000\end{array}$ & 0,518 \\
\hline
\end{tabular}

Rerata stress pada hasil penelitian ini adalah 9,9 pada kategori stress ringan. Kondisi ini dimungkinkan karena pandemi telah berjalan selama kurang lebih 6 bulan dan di saat WHO telah menetapkan masuk era New Normal atau Adaptasi Kebiasaan Baru (AKB). Setiap situasi yang menyebabkan perubahan dan mengharuskan adaptasi dalam menjalankannya dapat disebut sebagai kondisi stress. Stres akut bisa menjadi positif menimbulkan energi jiwa yang membangkitkan motivasi dalam pencapaian tujuan. Namun stres akut yang tidak dapat dikelola dengan baik dan berlangsung lama bahkan berulang dapat menjadi stres kronis serta mengganggu stabilitas mental individu. Selanjutnya gangguan psikologis tersebut dapat menimbulkan gejala fungsi organ dikarenakan penurunan system imunitas (Mina, Zeljko, \& Kristina 2019).

Level stres tinggi di awal kemunculan stressor. Begitu pula dengan stres yang disebabkan oleh Covid-19 ini. Sebuah penelitian di China yang menilai stress pada tanggal 31 Januari hingga 2 Februari 2020 yaitu fase awal wabah didapatkan respon stres yang berat pada separuh responden dan sepertiganya mengalami stres sedang hingga berat. Informasi kesehatan yang adekuat tentang Covid-19 seperti pengobatan, kondisi wabah lokal, dan pencegahan (Gerakan pakai masker dan cuci tangan) berdistribusi pada tingkat stres yang rendah (Wang et al. 2019). Dengan demikian promosi dan edukasi tentang Covid19 perlu terus digalakkan guna mempertahankan status mental masyarakat secara umum yang akan berdampak juga pada ketahanan mental perawat.

Sebuah hasil penelitian yang cukup menarik tentang kondisi stres yang dialami perawat di Hubei China tempat pertama kali kasus Covid-19 ditemukan, menunjukkan kondisi stress perawat yang berada di lini depan lebih rendah dibandingkan perawat yang berada di non lini depan. Stress pada perawat non lini depan tidak mengalami perbedaan yang signifikan bila dibandingkan dengan masyarakat umum (Lia et al. 2020). Bila kita melihat ke lapangan perawat di lini terdepan yaitu mereka yang berada pada zona merah merawat pasien yang telah dinyatakan positif terkonfirmasi Covid-19. Perawat di lini depan menggunakan Alat Pelindung Diri (APD) level 3 sampai 4 pada ruang khusus bertekanan negatif. Sementara perawatperawat yang berada dizona kuning dengan APD yang terbatas seringkali mengalami keterpaparan infeksi akibat pasien yang kurang jujur saat dalam menceritakan riwayatnya. APD yang tersedia secara adekuat memberikan kenyamanan psikologis pada perawat dalam menjalankan tugasnya. 
Volume 6, Issue 2, Year 2020, Pages 57-65

Peraway yang menjalankan tugas di masa pandemi Covid-19 seperti berada di medan pertempuran dengan musuh yang tidak kasat mata. Diperlukan intervensi kontinu untuk mempertahankan ketangguhan mental perawat. Terdapat tujuh kategori dukungan yang dibutuhkan oleh perawat untuk memberikan performa perawatan yang berkualitas di masa pandemi ini. Ketujuh kategori tersebut adalah APD, komunikasi, pembiayaan, masalah industri, tempat kerja, perawatan diri serta rekan profesi dan kepemimpinan (Halcomb et al. 2020).

Sementara itu di Indonesia, sejak merebaknya wabah ini di Wuhan China akhir Desember 2019 kemudian bulan Januari 2020 dinyatakan sebagai kedaruratan Internasional yang kemudian ditetapkan menjadi pandemi oleh WHO pada tanggal 11 Maret, Covid-19 memberikan berbagai dampak. Dampak yang terjadi tidak hanya di bidang kesehatan saja, melainkan juga dampak di bidang ekonomi, sosial, pendidikan serta bidang-bidang lainnya. Mengingat hal tersebut maka kebijakan lockdown menimbulkan gejolak di masyarakat. Pandemi masih mungkin berlangsung lama maka ditetapkanlah suatu adaptasi kebiasaan baru. Belum ditemukan vaksin serta obat yang efektif, menjadikan hidup bersama Covid-19 sebagai kenyataan yang tak terelakkan. Roda kehidupan harus kembali berjalan dengan kebiasaan menerapkan protokol pencegahan Covid-19. Prinsip utama protokol tersebut adalah $5 \mathrm{M}$; Memakai Masker, Menjaga jarak, Mencuci tangan, Makan makanan bergizi, Memohon pertolongan Tuhan Yang Maha Esa, namun demikian implikasi dari AKB adalah peningkatan risiko penularan. Kepatuhan masyarakat dalam menjalankan protokol kesehatan pencegahan Covid-19 menjadi kunci utama untuk meredam risiko penularan. Peran media sosial dapat dimanfaatkan untuk pemberian edukasi kepada masyarakat. Dengan jumlah pengguna media sosial yang banyak dan menjangkau hampir di semua lapisan masyarakat maka pesan kesehatan dapat disampaikan secara luas secara bersamaan (Sampurno, Kusumandyoko, and Islam 2020). Masyarakat sebagai pemakai jasa pelayanan dari pusat kesehatan merupakan salah satu faktor dukungan sosial yang berdistribusi terhadap ketahanan mental perawat.

Dukungan sosial masyarakat merupakan faktor penting dalam ketahanan mental perawat (Kılınc and Sis Celik 2020). Berbagai macam persepsi masyarakat terkait pandemi ini. Persepsi inilah yang memengaruhi dukungan mereka terhadap tenaga Kesehatan. Kemampuan perawat bertahan untuk menjalankan tugasnya walaupun di tengah dukungan sosial yang rendah menjadi tantangan tersendiri. Dukungan sosial yang rendah ini mungkin disebabkan faktor stigma yang ada di masyarakat. Stigma juga terbentuk akibat media sosial online yang terkadang liar menyebarkan hoaks (Santoso \& Santosa 2020).

Kejadian nyata di Indonesia akibat stigma dan diskriminasi terhadap tenaga kesehatan berupa pengusiran dari tempat tinggal, jenazah perawat yang ditolak, dikucilkan, larangan naik kendaraan umum dan lain sebagainya. Stigma dapat menjadi penghalang keberhasilan bagi upaya kesehatan mental secara universal. Kesehatan mental harus menjadi bagian yang terintegrasi dalam upaya kesehatan secara general. Mengingat dampak psikososial yang diakibatkan Covid-19 maka WHO menetapkan kesehatan mental sebagai bagian yang terintegrasi dalam upaya penanggulangan Covid-19. Upaya tersebut perlu dilakukan dengan pendekatan berbasis masyarakat. Meningkatkan partisipasi dengan memberdayakan masyarakat serta kebijakan buttom up diperlukan untuk menghentikan stigma. Model konsep tersebut sesuai dengan aplikasi program desa siaga yang melibatkan masyarakat sebagai subjek kebijakan. Program desa siaga ini telah diinisiasi oleh Kementrian Kesehatan tahun 2018 untuk memandirikan masyarakat dalam penanggulangan bencana dan kegawatdaruratan secara mandiri (Kackin et al. 2020; Ridlo 2020). 
Volume 6, Issue 2, Year 2020, Pages 57-65

Kondisi rerata dukungan sosial dan kecerdasan spiritual yang dibawah nilai tengah dengan kondisi stress stres ringan menunjukkan ada faktor lain yang lebih memengaruhi ketahanan mental perawat dalam menjalankan tugasnya. Faktor individu dan faktor organisasi dapat berkontribusi terhadap kondisi stres serta ketangguhan mental perawat (El-hage et al. 2020; Labrague and de los Santos 2020). Kehandalan manajemen Rumah Sakit maupun pusat-pusat pelayanan kesehatan lainnya dalam mereorganisasi dan merstrukturisasi sangat diperlukan untuk menangani wabah ini. Covid-19 menyebabkan kondisi tidak terduga dan belum pernah terjadi sebelumnya. Hal tersebut membuat Rumah sakit serta pusat-pusat layanan kesehatan harus tanggap dan beradaptasi cepat. Penyediaan APD yang adekuat, regulasi rotasi perawat, penyediaan tempat karantina dan transportasi ke Rumah Sakit. Ripp dan kawan-kawan tahun 2020 menulis tiga area prioritas yang perlu disediakan pihak manajemen adalah kebutuhan dasar, komunikasi dan dukungan kesehatan mental dan psikososial. Kebutuhan dasar tersebut berupa penyediaan makan gratis yang higienis, penginapan tempat karantina yang nyaman, transportasi, keselamatan diri berupa APD yang adekuat, penyediaan bahan desinfektan, scrubing, panduan yang jelas tentang prinsip isolasi sehingga terhindar dari tertular dan menularkan kepada orang-orang yang disayangi serta perawatan anak yang ditinggalkan selama karantina saat bertugas. Jaringan komunikasi dalam sistem layanan kesehatan dan pribadi. untuk dukungan psikososial dan kesehatan mental berbagai intervensi ditawarkan seperti baik di tingkat individu maupun tingkat kelompok. Tak kalah penting beban ekonomi sebagai dampak dari Covid-19 juga memengaruhi stres perawat oleh karena itu penting bagi pihak manajemen untuk memberikan intensif perawat sebagai penghargaan terhadap risiko kerja yang mereka hadapi (Almaghrabi et al. 2020; Ripp, Peccoralo, and Charney 2020).

Ketangguhan perawat menghadapi wabah Covid-19 sangat dipengaruhi oleh faktor internal mereka. Salah satu faktor internal tersebut adalah kecerdasan spiritual (Sahebalzamani et al. 2013; Torabi and Nadali 2016). Beberapa penelitian menunjukkan besarnya pengaruh faktor spiritual dalam pencegahan stres perawat dan performa kinerja perawat yang secara tidak langsung meningkatkan kepuasan pasien (Fashi 2017; Haryono, Rosady, and Shamsuri MdSaad 2018; Heydari, Meshkinyazd, and Soudmand 2017). Covid19 telah membuat krisis bagi pelayanan Kesehatan. Krisis yang terjadi harus dapat dikelola dengan baik agar ditemukan suatu formula adaptasi yang memberikan kekuatan mental dalam menghadapinya. Situasi krisis menciptakan stres bagi perawat, kecerdasan spiritual perawat berhubungan terbalik dan signifikan dengan nilai $r=-0,243$ dan $P=0,009$ (Shahrokhi, N. Elikaei, L. Yekefallah 2018). Sekali lagi disini pihak manajemen Rumah Sakit perlu proaktif untuk mempertahankan kesejahteraan mental perawat. Intervensi monitoring dan pelatihan manajemen stres penting untuk dilaksanakan (Salopek-Žiha et al. 2020).

Proses mempertahankan kesehatan psikososial dan mental tenaga kesehatan menjadi pembahasan penting di banyak negara. Untuk memberikan layanan yang prima tentunya tenaga kesehatan haruslah sehat terlebih dahulu serta memiliki rasa kenyamanan dalam bekerja. Berbagai upaya dapat dilakukan untuk mempertahankan kesehatan mental tenaga kesehatan khususnya perawat seperti pelatihan manajemen stres, meditasi, yoga, diskusi kelompok. Strategi dilakukan baik oleh pribadi perawat maupun oleh institusi tempat mereka bekerja (Heath, Sommerfield, and von Ungern-Sternberg 2020).

\section{SIMPULAN DAN SARAN}

Dukungan sosial dan kecerdasan spiritual merupakan faktor yang memengaruhi kondisi stres perawat yang bekerja di masa pandemi Covid-19. Semakin tinggi dukungan sosial dan kecerdasan spiritual maka semakin rendah stress yang dialami perawat. Mengingat hal tersebut dan menimbang pandemi yang 
Volume 6, Issue 2, Year 2020, Pages 57-65

belum dapat ditentukan secara pasti kapan berakhir maka pihak manajemen perlu melakukan upaya mempertahankan kesehatan psikososial dan mental perawat. Bentuk upaya tersebut berupa support sarana dan prasarana dalam bertugas seperti APD, pelatihan management safety, prosedur pemeriksaan kesehatan, fasilitas komunikasi selama proses karantina, insentif risiko juga pelatihan-pelatihan manajemen stres. Pemerintah perlu melakukan pendekatan dengan model partisipatif dan kebijakan buttom up guna mengarahkan kepatuhan masyarakat terhadap protokol kesehatan dan meminimalkan stigma.

\section{DAFTAR PUSTAKA}

Albott, Cristina Sophia, Jeffrey R. Wozniak, Brian P. McGlinch, Michael H. Wall, Barbara S. Gold, and Sophia Vinogradov. 2020. "Battle Buddies: Rapid Deployment of a Psychological Resilience Intervention for Health Care Workers during the COVID-19 Pandemic." Anesthesia and Analgesia XXX(Xxx):43-54.

Almaghrabi, Rana H., Huda A. Alfaraidi, Wejdan A. Al Hebshi, and Mohammed M. Albaadani. 2020. "Healthcare Workers Experience in Dealing with Coronavirus (COVID-19) Pandemic." Saudi Medical Journal 41(6):657-60.

El-hage, W., C. Hingray, C. Lemogne, A. Yrondi, P. Brunault, and T. Bienvenu. 2020. "Health Professionals Facing the Coronavirus Disease 2019 (COVID-19) Pandemic: What Are the Mental Health Risks? W." (January).

Fashi, Fatemeh Merati. 2017. "Studying the Relationship between Spiritual Intelligence of Nurses and Patients' Satisfaction with Nursing Care." Bali Medical Journal 6(3):539.

Halcomb, Elizabeth, Anna Williams, Christine Ashley, Susan Mclnnes, Catherine Stephen, Kaara Calma, and Sharon James. 2020. "The Support Needs of Australian Primary Health Care Nurses during the COVID-19 Pandemic." Journal of Nursing Management 28(7):1553-60.

Haryono, Siswoyo, Febry Rosady, and Mohd Shamsuri MdSaad. 2018. "Effects of Emotional and Spiritual Intelligence on Job Performance among Temporary Nurses at Abdul Riva'i Regional General Hospital, Berau District, East Kalimantan Province, Indonesia." Management Issues in Healthcare System 4(1):42-54.

Heath, C., A. Sommerfield, and B. S. von Ungern-Sternberg. 2020. "Resilience Strategies to Manage Psychological Distress among Healthcare Workers during the COVID-19 Pandemic: A Narrative Review." Anaesthesia 75(10):1364-71.

Heydari, Abbas, Ali Meshkinyazd, and Parvaneh Soudmand. 2017. "The Effect of Spiritual Intelligence Training on Job Satisfaction of Psychiatric Nurses." Iranian Journal of Psychiatry 12(2):128-33.

IDI, PB. 2020. Pedoman Standar Perlindungan Dokter Di Era Covid-19.

Kackin, Ozlem, Emre Ciydem, Ozgur Sema Aci, and Fatma Yasemin Kutlu. 2020. "Experiences and Psychosocial Problems of Nurses Caring for Patients Diagnosed with COVID-19 in Turkey: A Qualitative Study." International Journal of Social Psychiatry. 
Volume 6, Issue 2, Year 2020, Pages 57-65

Kim, Young-Jae, So-Young Lee, and Jeong-Hyung Cho. 2020. "A Study on the Job Retention Intention of Nurses Based on Social Support in the COVID-19 Situation." Sustainability 12(18):7276.

Kılınç, Tülay, and Aslı Sis Çelik. 2020. "Relationship between the Social Support and Psychological Resilience Levels Perceived by Nurses during the COVID-19 Pandemic: A Study from Turkey." Perspectives in Psychiatric Care (June):1-9.

Labrague, Leodoro J., and Janet Alexis A. de los Santos. 2020. "Fear of COVID-19, Psychological Distress, Work Satisfaction and Turnover Intention among Frontline Nurses." Journal of Nursing Management (August):1-9.

Lia, Zhenyu, Jingwu Gea, Meiling Yanga, Jianping Fenga, Mei Qiaoa, Riyue Jiangb, Jiangjiang Bic, Gaofeng Zhanc, Xiaolin Xuc, Long Wangd, Qin Zhoub, Chenliang Zhoue, Yinbing Pana, Shijiang Liua, Haiwei Zhanga, Jianjun Yangf, Bin Zhug, Yimin Huh, and Chun Yanga. 2020. "Vicarious Traumatization in the General Public, Members, and Non-Members of Medical Teams Aiding in COVID-19 Control." Brain, Behavior, and Immunity 87(January):25-26.

Luo, Min, Lixia Guo, Mingzhou Yu, Wenying Jiang, and Haiyan Wang. 2020. "The Psychological and Mental Impact of Coronavirus Disease 2019 (COVID- 19) on Medical Staff and General Public - A Systematic Review and Meta- Analysis." (January).

Mina, Cvjetkovi\} Bo\{njak, Dubovski Poslon Milota Bibi\} Zeljko, and Bo\{njak Kristina. 2019. "THE INFLUENCE OF CHRONIC STRESS ON HEALTH AND COPING MECHANISMS." 14(1):97-101.

Rejo, Dewi Arradini, Aris Darmayanti, Aquartuti Tri, Widiyanto, and Joko Tri Atmojo. 2020. "Faktor-Faktor Yang Berhubungan Dengan Depresi Pada Tenaga Kesehatan Saat Pandemi Covid-19." Urnal IImu Keperawatan Jiwa 3(4):495-502.

Ridlo, Ilham Akhsanu. 2020. "Pandemi COVID-19 Dan Tantangan Kebijakan Kesehatan Mental Di Indonesia INSAN Jurnal Psikologi Dan Kesehatan Mental Pandemi COVID-19 Dan Tantangan Kebijakan Kesehatan Mental Di Indonesia." (November).

Ripp, Jonathan, Lauren Peccoralo, and Dennis Charney. 2020. "Attending to the Emotional Well-Being of the Health Care Workforce in a New York City Health System During the COVID-19 Pandemic." Academic Medicine : Journal of the Association of American Medical Colleges 95(8):1136-39.

Sahebalzamani, Mohammad, Hojjatollah Farahani, Reza Abasi, and Mehdi Talebi. 2013. "The Relationship between Spiritual Intelligence with Psychological Well-Being and Purpose in Life of Nurses." Iranian Journal of Nursing and Midwifery Research 18(1):38-41.

Salopek-Žiha, Darija, Marina Hlavati, Zvjezdana Gvozdanovi, Mario Gaši, Harolt Placento, Hrvoje Jaki, Denis Klapan, and Hrvoje Šimi. 2020. "Differences in Distress and Coping with the Covid-19 Stressor in Nurses and Physicians." Psychiatria Danubina 32(2):287-93.

Sampurno, Muchammad Bayu Tejo, Tri Cahyo Kusumandyoko, and Muh Ariffudin Islam. 2020. "Budaya Media Sosial, Edukasi Masyarakat, Dan Pandemi COVID-19." SALAM: Jurnal Sosial Dan Budaya Syar- 
17(5).

Santoso, Didik Santoso, and Awan Santosa. 2020. Covid-19 Dalam Ragam Tinjauan Perspektif. 1st ed. edited by D. H. S. A. Santosa. DI Yogyakarta: MBrigee Press.

Shahrokhi, N. Elikaei, L. Yekefallah, A. Barikani. 2018. "Relationship between Spiritual Intelligence and Perceived Stress among Critical Care Nurses." 22(3):40-49.

Torabi, Mohsen, and ImanZohoorian Nadali. 2016. "When Does Spiritual Intelligence Particularly Predict Job Engagement? The Mediating Role of Psychological Empowerment." Iranian Journal of Nursing and Midwifery Research 21(6):589.

Wang, Cuiyan, Riyu Pan, Xiaoyang Wan, Yilin Tan, Linkang Xu, Cyrus S. Ho, and Roger C. Ho. 2019. "Immediate Psychological Responses and Associated Factors during the Initial Stage of the 2019 Coronavirus Disease ( COVID-19 ) Epidemic among the General Population in China."

Wei,X.S. Wang, X.R. Zhang, J. .. et al. 2020. "A Cluster of Health Care Workers with COVID-19 Pneumonia Caused by SARS-CoV-2." Journal of Microbiology, Immunology and Infection (January):1-7. 